\title{
Os entrecruzamentos socioculturais como performances em Rashomon de Akira Kurosawa
}

Anne Araujo Vilela*

\section{Resumo}

Este artigo examina as características históricas e sociais do filme Rashomon de Akira Kurosawa, pelo prisma das performances culturais, pois analisa os discursos de natureza sociocultural. O filme de 1950 consiste em uma adaptação de dois contos do escritor moderno japonês Ryunosuke Akutagawa (1892-1927) e possui uma estrutura extremamente rica quando visto à luz das performances.

Palavras-chave: história; cinema japonês; performances culturais.

\begin{abstract}
This article examines the historical and social characteristics of Akira Kurosawa's Rashomon film, through the prism of cultural performances, analyzing discourses of a sociocultural nature. The 1950 film is an adaptation of two short stories by the modern Japanese writer Ryunosuke Akutagawa (1892-1927) and has an extremely rich structure when seen in the light of performances.
\end{abstract}

Keywords: story; japanese cinema; cultural performances.

\section{Introdução}

O primeiro filme japonês de grande repercussão, que abriu as portas do cinema nipônico para o Ocidente, Rashomon representa uma obra-prima do cinema, assim como Akira Kurosawa se sobressai como um dos renomados diretores da história. A narrativa se baseia em dois contos do escritor moderno japonês Ryunosuke Akutagawa e, apesar do filme se passar na era Heian (794-1192)1, reforça a realidade vivida pelos japoneses no período contemporâneo à produção do filme (KUROSAWA, 1982). O filme Rashomon agradava tanto orientais quanto ocidentais, tendo em vista que Kurosawa era um grande conhecedor da cinematografia e literatura ocidentais e, portanto, tinha o domínio para utilizar

\footnotetext{
* Produtora cultural no Instituto Federal de Educação, Ciência e Tecnologia de Goiás (IFG). Bacharel em Comunicação Social com habilitação em Audiovisual pela Universidade Estadual de Goiás (UEG). Especialista em História da Arte. Mestranda em Performances Culturais pela Universidade Federal de Goiás (UFG). Pesquisa as áreas relacionadas não só às narrativas audiovisuais (cinema e TV) e suas relações socioculturais e históricas, assim como suas características performáticas.

${ }^{1}$ O período Heian teve início em 794, após a mudança da capital do Japão para Heian kyō (atualmente Quioto), pelo quinquagésimo imperador japonês, Kammu.
} 
formas de arremate da narrativa habituais do Ocidente, permitindo o fácil entendimento da história inclusive por espectadores desprovidos de qualquer conhecimento prévio acerca do Japão.

Ao mesmo tempo, Rashomon era legitimado pelo público japonês, pois a era Heian (794-1192) ainda é muito venerada por ter sido o momento de ascensão da cultura samurai. Ademais, tratou-se de um período de grande decadência social para as classes mais pobres, situação revivida na memória coletiva japonesa com o abatimento da população após a derrota do país na Segunda Guerra Mundial (19391945). O Japão encontrava-se devastado, as cidades destruídas, havia uma enorme agitação política e a ocupação norte-americana trouxe problemas, como o choque ideológico. A partir disso, eram impostos novos valores individuais do Ocidente, levados a força pela presença estrangeira.

Neste sentido, a identificação do público japonês com Rahomon ocorreu através da memória coletiva ao trazer a representação do passado compartilhada pelos membros de um mesmo grupo, refletindo em um contexto sociocultural amplo. Nas palavras de Wertsh:

\begin{abstract}
[...] os recursos textuais usados na memória coletiva geralmente não tomam a forma de unidades isoladas, hermeticamente fechadas, que são usadas de forma não modificada e na sua totalidade ou não são usadas de forma alguma. Em vez disso, eles constituem um tipo de instrumento muito mais flexível que pode ser aproveitado em combinação com outros de maneiras novas (WERTSH, 2004, p. 7, tradução nossa)
\end{abstract}

\title{
História e cultura em Rashomon
}

Akira Kurosawa nasceu em 1910 na cidade de Tóquio e tinha mais sete irmãos. Em sua educação básica as melhores notas eram referentes às artes e à redação. Na juventude passou a dedicar boa parte de suas horas à leitura e ao estudo das artes, tornando-se, mais tarde, quase profissional em pintura (KUROSAWA, 1982; RICHIE, 1971). Após um tempo de indecisão em relação ao que fazer da vida, em 1935, aos 26 anos, Kurosawa ingressou na produtora PCL (Photo Chemical Laboratory), como assistente de diretor e, daí em diante, exerceu diversas funções dentro da atividade cinematográfica, onde se destacou como roteirista. Durante esse período da carreira, teve a oportunidade de aprender com mestres, como Mikio Naruse e Kajiro Yamamoto, este um dos influentes diretores de filmes do período pré-guerra japonês. Em 1943, Kurosawa começou a trabalhar como diretor nos estúdios da Toho, estreando com o filme Sugata Sanshirô (KUROSAWA, 1982; RICHIE, 1971). Esta fase da vida de Kurosawa até se tornar realmente 
diretor, pode ter direcionado e interferido na construção de suas obras cinematográficas, pois era um ávido leitor de obras literárias ocidentais, conhecedor da estética das artes plásticas, música, teatro e cinema, além de compactuar da retórica populista, fazendo com que houvesse um direcionamento em suas obras permeadas por uma visão de mundo tão apurada, chegando ao filme Rashomon.

O filme aqui analisado tratava da história de crimes relacionados à morte de um homem e ao estupro da esposa em um bosque. Diante do ocorrido, seis pessoas depõem sobre o caso, cujos testemunhos são narrados por um lenhador e um monge budista a um camponês, enquanto esperam a chuva cessar sob o portal de um templo chamado Rashomon. O Lenhador encontrara o corpo, enquanto o Monge havia visto o casal antes dos crimes ocorrerem. O longa-metragem é baseado nos dois contos Rashomon, de 1915 e Yabuno naka (Dentro do Bosque), de 1922, representações de narrativas do século XII. De acordo com Ueda (1976), Akutagawa foi um escritor moderno japonês tendo sido um dos primeiros a provar para os outros que pequenas histórias podem fazer sucesso quando atualizadas para um tema moderno, portanto, pode-se reescrever antigas histórias japonesas atualizando a temática para que o público se identifique. Esta lógica narrativa também foi aproveitada da literatura para o cinema por Kurosawa em Rashomon, pois os japoneses não estavam acostumados com histórias orais, literárias, teatrais ou cinematográficas que não fossem previamente compreendidas e interpretadas.

Os contos não deixavam de ser atuais, visto que o desolamento sentido no filme não apenas havia sido vivenciado na era Heian, e revivenciada diversas vezes no decorrer do tempo no Japão, como também estava sendo experimentada naquele momento pelo povo japonês que atravessava o fim da Segunda Guerra Mundial, em 1945. Portanto, Akira Kurosawa conseguiu fazer uma contextualização e a sobreposição de memórias, através de realidades e ficções, atuando entre a sensibilidade e a razão, deslocando a percepção de representações do passado (Era Heian) para o Japão do pós-guerra. Além disso, trouxe para o filme dimensões estéticas, políticas, religiosas e morais de si próprio. Dado que, muitas vezes, as experiências são também contadas como histórias, Rashomon pode ser considerado um evento performático, pois como define Bauman (1977), a performance pode ser um segmento limitado e culturalmente definido do fluxo de comportamento e da experiência que constitui um contexto significativo para a ação, em que as experiências são também contadas como histórias. Assim, um filme, principalmente como Rashomon que conta histórias já experienciadas pelos japoneses histórica e coletivamente, serve como instrumento para o entendimento do seu contexto contemporâneo de maneira nova, podendo ser, portanto, uma performance. 
Esta sobreposição de memórias constitui o filme Rashomon em uma relação entre realidade e ficção. Segundo Hartmann (2005), pode ser aferido como a tensão inevitável entre a realidade, a experiência e as expressões (como a experiência individual é enquadrada e articulada), e as possíveis chaves para a interpretação dos seus significados. Assim, as narrativas surgem enquanto forma de expressão inserida no fluxo da ação social, visto estarem conectadas com o seu contexto sócio-histórico.

\title{
O jogo performático nas vozes sociais dos personagens
}

Para Bauman (2004), os repertórios culturais e práticas servem de referenciais de orientação para a produção, recepção e circulação do discurso, com coerência sócio-histórica. Logo, a voz do diretor e autor, Akira Kurosawa, confundese sobretudo com a do personagem Lenhador, posto que este conduz as outras vozes ao mesmo tempo em que deixa estas se manifestarem com autonomia. Desse modo, o Lenhador cumpre também a função de um contador de histórias, benshi, ${ }^{1}$ relatando os depoimentos ouvidos e o que vivenciou, manipula a narrativa a fim de ludibriar o Plebeu, o Monge e os espectadores do filme. Sob essa premissa, Goffman (2011) afirma que este tipo de situação ocorre:

\begin{abstract}
Quando o indivíduo se envolve exageradamente no tópico da conversação, e dá aos outros a impressão de que não tem um grau necessário de autocontrole sobre seus sentimentos e ações, quando, resumindo, o mundo da interação fica real demais para ele, então é provável que os outros sejam levados do envolvimento com a conversa a um envolvimento com o orador. A animação exagerada de uma pessoa é a alienação de outra. (GOFFMAN, 2011, p. 119)
\end{abstract}

Assim, durante o filme dá-se início a um jogo, em que diversos pontos de vista são colocados em contraposição. Cada personagem tenta convencer o espectador ao contar a sua história, tentando persuadi-lo de sua honestidade e verdade. No entanto, percebe-se, geralmente, que todo o jogo é controlado pelo Lenhador, premissa que sustenta a ideia de Goffman (2011, p. 17), de que uma pessoa assume a responsabilidade de fiscalizar o fluxo: "Ao entrar numa situação em que recebe uma fachada para manter, essa pessoa assume a responsabilidade de vigiar o fluxo de eventos que passa diante dela".

Para o referido autor, o espectador também oferece sua atenção auditiva e, normalmente, também visual para a fonte da comunicação. Por isso, entende-se

1 O Benshi era um "narrador-comentador-explicador", como chama Richie (2005), narra uma história, cujo sentido, na maioria das vezes, estava em sua própria construção, além de comentar o aparente. 
que em Rashomon, o espectador se vê envolvido em uma narrativa como se participasse da conversação sob o portal durante a tempestade e deixa-se seduzir por cada uma das versões do crime ocorrido no bosque, gerando uma afeição entre o espectador e os personagens. Esse tipo de situação para Goffman (2011, p. 61) acontece posto que: "A apreciação comunicada por um ato de deferência implica que $o$ ator possui um sentimento de estima pelo receptor, o que muitas vezes envolve uma avaliação geral do receptor".

Portanto, em Rashomon, os personagens tentam convencer o telespectador ao falarem direto para a câmera, pois todos os envolvidos na cena do crime têm o seu momento de narração e trazem o enfoque para a sua versão dos fatos. Como em um documentário, os atores transfigurados em personagens fornecem seus depoimentos diante de uma corte, para um interlocutor que não sabemos quem é na verdade e que pode ser o telespectador. Tudo ocorre como se fossem depoimentos para um documentário, propiciando realismo ao filme.

Há quem diga que esses depoimentos dos personagens do filme podem ser comparados com relatos de presos de guerra: testemunhos desencontrados que sempre pareciam indicar a inocência deles próprios. Além disso, o aparecimento de uma Médium para depor pode ter sido usado para criticar o xintoísmo ${ }^{1}$ no país, quase sempre ligado ao nacionalismo japonês, o qual fez com que o país entrasse na Segunda Guerra como aliado da Alemanha e acabasse destruído ao perder. O Japão havia sido atacado por duas bombas nucleares e invadido pelas forças compostas pelos Estados Unidos.

Ademais, Kurosawa, modificou alguns elementos dos contos para conseguir criar um clima de suspense na história, intercalando os depoimentos com comentários dos três sob o portal, acrescentando um final surpreendente. Apesar dos japoneses não estarem acostumados historicamente com o suspense, a narrativa não Ihes era totalmente desconhecida, a surpresa provavelmente servia para agradar aos ocidentais. Assim, todos no filme têm direito a uma parcela da narração, a uma porcentagem da ficção. Contudo, sabe-se que a voz pode ser diferente do discurso e da importância da voz social por trás de cada uma dessas pequenas narrações:

1 O xintoísmo tornou-se conhecido por seu nacionalismo fervoroso e pela crença concomitante de que os japoneses eram uma raça superior. Foi essa atitude, nutrida por muitos anos, que conduziu à ofensiva japonesa durante a Segunda Guerra Mundial. A força da fé que muitos tinham em seu imperador, Hirohito, foi demonstrada pelas ações de pilotos camicases ou bombardeiros suicidas que escolheram morrer em seu benefício (FARRINGTON, 1999 , p. 85 , grifo do autor). 
A questão, quase literalmente, não é tanto a cor do rosto que aparece na imagem, mas a voz social real ou figurativa que fala "através" da imagem. Menos importante que a "acuidade mimética" do filme é sua capacidade de transmitir as vozes e perspectivas da comunidade ou comunidades em questão. (STAM; SHOHAT, 2006, p. 310).

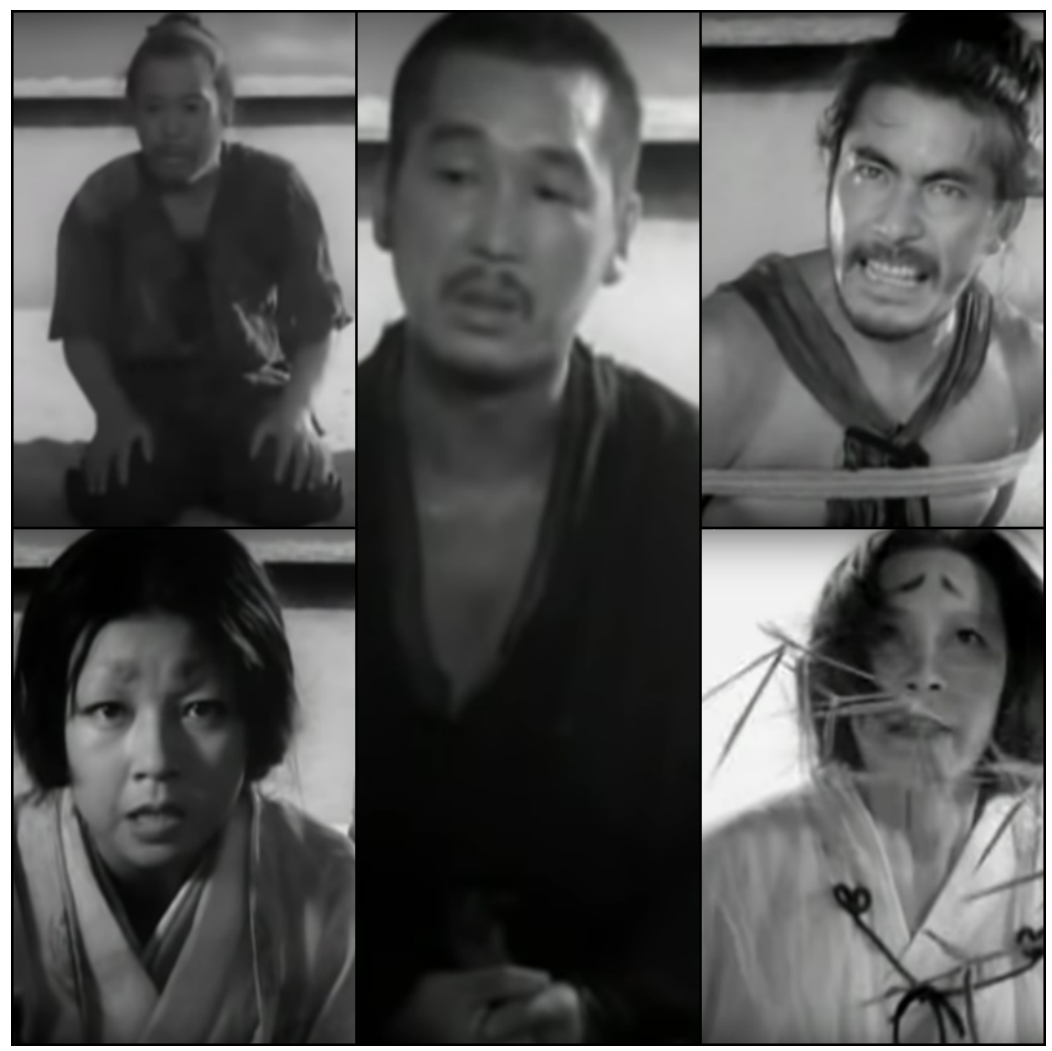

Figura 1 - Depoimentos do Lenhador, da Esposa, do Monge, do bandido Tajomaru e da Médium.

Portanto, todo o filme é claramente uma obra polifônica, onde o autor continua presente, atuando como o regente das vozes que participam do processo dialógico, além dos três, sob o portal, há cinco depoimentos no Palácio da Justiça (Figura 1). Na polifonia há maior produção de sentidos, pois o texto não se fecha em um único ponto de vista, assim, para Bakhtin (1981, p. 12), a polifonia se define pela "unificação das matérias mais heterogêneas e mais incompatíveis".

Nesse viés, para Bakhtin (2003, p. 294): "a experiência discursiva individual de qualquer pessoa se forma e se desenvolve em uma interação constante e contínua com os enunciados individuais dos outros". Nessa direção, o conceito de performances culturais considera que, improvisadamente, estas se relacionam à polifonia e aos contextos sociais. Bauman (2004), por exemplo, esclarece que uma 
narrativa não pode ser compreendida sem o contexto, pois a vida é socialmente constituída, produzida e reproduzida discursivamente através de práticas significantes, que se sustentam em seus contextos situacionais, amarrados pelo interdiscurso: situações, atos e diversos enunciados.

Assim como Bauman se preocupava com o discurso na vida social, Erving Goffman, sociólogo e antropólogo, procurou, na dramaturgia, uma perspectiva mais abrangente para o estudo das interações sociais, através da qual também construiu um modelo de performance mais conectado aos significados sócio-históricos completando o seu estudo das interações sociais. Em concordância com Goffman (2012), o desenvolvimento das dissimulações na vida social é definido através do "quadro", da "fachada" e da "performance". Logo, para Goffman (2014), a vida social pode ser dramatúrgica e a performance estar na vida cotidiana, ao mesmo tempo em que um evento pode ser performance para Bauman (1977). O filme também possui refrações ideológicas em toda a sua extensão, aqui explicadas dentro de seus contextos históricos e socioculturais. De maneira geral, os índices possuem valor ideológico, embora sejam realizados através de um indivíduo ou uma organização, contudo, são também índices sociais, pois cada signo possui um tema, um tema ideológico que sempre terá valor social. Para Bakhtin (2014, p. 46), os índices: "[...] se tornam, de certa forma, índices individuais desvelados, na medida em que a consciência individual os absorve como sendo seus, mas sua fonte não se encontra na consciência individual".

Para Bakhtin (2014), todo signo cultural torna-se parte da unidade da consciência verbalmente constituída. Ao passo que, para Stam e Shohat, a arte não é somente uma reflexão da realidade, bem como um processo de intervenção da realidade na fiç̧ão cinematográfica: "Fiç̧ões cinematográficas inevitavelmente trazem à tona visões da vida real não apenas sobre o tempo e o espaço, mas também sobre relações sociais e culturais" (STAM; SHOHAT, 2006, p. 262). Um dos exemplos no filme Rashomon é a manifestação, através de uma Médium, do espírito do Marido morto, ou seja, uma representação típica da cultura xintoísta, que traz muitos elementos da cultura e história japonesa.

Em conformidade com Yamashiro (1985) e Farrington (1999), o Xintoísmo incorpora práticas espirituais derivadas de diversas tradições pré-históricas japonesas, porém não surgiu como instituição religiosa até a chegada do Budismo. Com o advento deste no Japão, misturou-se com o Xintoísmo, principalmente na era Heian, quando se alastrou a ideia de que não havia diferença entre os deuses xintoístas e Buda. Em virtude desta adaptação do Xintoísmo ao Budismo, verificase, no filme, a defesa do depoimento da Médium pelo Monge budista ao afirmar que 
os homens mortos não mentem. Observa-se, em antecipação ao depoimento da Médium, a imagem de uma estátua caída no chão sendo banhada pela chuva antes de se iniciar o depoimento (Figura 2), visto que nos santuários xintoístas, usualmente, uma estátua os guarda.

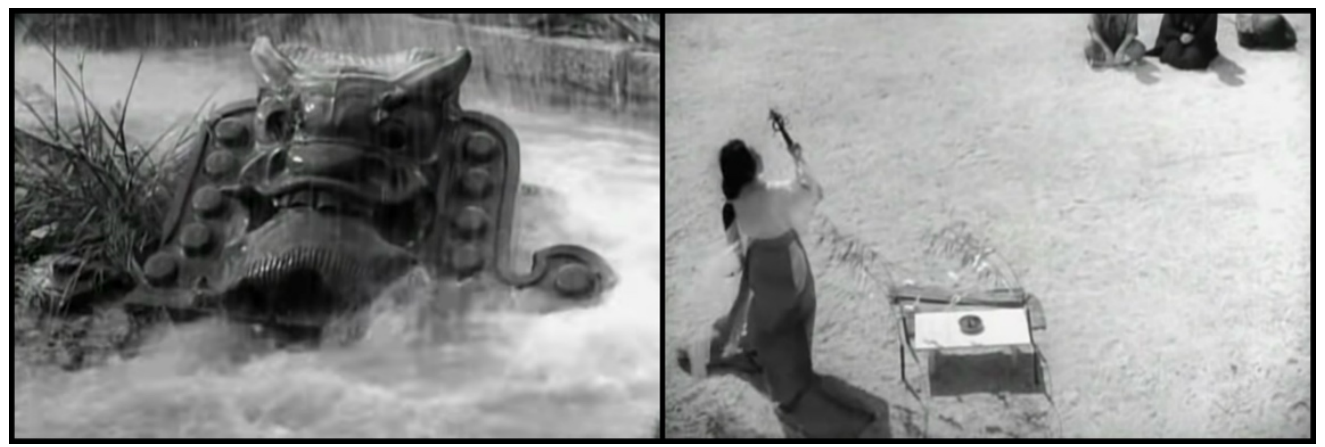

Figura 2 - Estátua xintoísta antes do depoimento da Médium e o ritual realizado por ela.

O ritual realizado pela Médium (Figura 2) pode ser o chamado o-harai, tipo de purificação parecida com exorcismo, em que se agita uma vara com tiras de papel penduradas.

\section{Rashomon, Dostoiévski e as performances das vozes sociais}

Kurosawa também se preocupou em desenvolver bem os comportamentos ínfimos ou ordinários de cada personagem em Rashomon com a finalidade de estruturar suas interações sociais na trama do filme. Isto ocorre devido ao fato dos personagens serem ficções criadas a partir de pessoas reais. Esses pessoas "reais", de acordo com Goffman (2011, p. 13), "[...] vivem num mundo de encontros sociais que as envolvem, ou em contato face a face, ou em contato mediado com outros participantes". Isto significa que, em cada contato face a face com outras pessoas, desempenha-se um padrão de atos verbais e não verbais, que compõem uma fachada, a impressão positiva causada socialmente por uma pessoa de forma voluntária nas demais. Nas palavras de Goffman (2011, p. 14): "A fachada é uma imagem do eu delineada em termos de atributos sociais aprovados."

Na escolha da fachada, após o contato de impressão, é levada em conta, especialmente, a capacidade de se manter e de lidar com as respostas dos outros a essa pequena "farsa". Segundo Goffman (2011, p. 14), "A pessoa tende a experimentar uma resposta emocional imediata à fachada que um contato com outros permite a ela; ela catexiza sua fachada; seus 'sentimentos' se ligam a ela". Além disso, sabe-se que a narrativa moderna de Dostoiévski influenciou 
decisivamente a cinematografia de Kurosawa, aliás, em Richie (1971), o diretor japonês evidencia que Dostoiévski ${ }^{1}$ era o seu autor predileto e considerava ter sido quem escreveu com mais honestidade sobre a existência humana. Provavelmente graças a isto, Kurosawa, reforçava a temática do drama humano em seus filmes.

A influência dos romances de Dostoiévski em Rashomon dá-se também através do uso do dialogismo, que resulta do embate de muitas vozes sociais, assim como ocorre com as várias versões da mesma história contadas em depoimentos no transcorrer do filme para a construção do enredo. Na visão de Bakhtin (1981), Dostoiévski trazia a polifonia em seus romances como decorrência da forma como aqueles personagens se inseriam no mundo. Ademais, o autor russo utilizava muito o romance de provas que, segundo Bakhtin (2003), é construído com a submissão do protagonista a diversas provas onde são postas em pauta sua lealdade, suas virtudes, sua santidade etc. Da mesma forma, nota-se que, nesse filme de Kurosawa, o Lenhador também passa por diversas provações em que se testam suas virtudes. Assim, apesar dos personagens de Kurosawa possuírem caráter polifônico, apresentam certo núcleo unificador, amarrando a trama, posto que, em Rashomon, o Lenhador, pouco a pouco, revela-se como personagem central, de quem sai a primeira e a última versão do que ocorrera no bosque.

Segundo a teoria de Goffman (2011), esse tipo de comportamento pode ser definido como fachada, pois sustenta o indivíduo socialmente, o qual para tornar sua ação convincente adota uma expressividade que fixa sua encenação. Portanto, o Lenhador faz uma boa demonstração de si mesmo a fim de ser aprovado pelos outros personagens no nível da ficção e pelos espectadores no nível "real", os quais, por sua vez, experimentando uma resposta emocional imediata à sua fachada, pois os outros se ligam sentimentalmente a ele. Ainda de acordo com Goffman, um indivíduo que mantém uma fachada passa sempre pelo temor de perder a consideração dos outros e seus sentimentos caso a máscara caia e, por isso, mantém um pequeno conjunto de outras fachadas para equilibrar a principal. Neste sentido, o Lenhador de Rashomon, em seu encontro com os outros sob o portal durante a chuva, convenciona um pequeno conjunto de fachadas para os desconhecidos com o intento de convencê-los de sua farsa.

Quando as fachadas do Lenhador são ameaçadas e entram em estado de desequilíbrio, há uma tentativa deste de restabelecer um estado ritual satisfatório,

1 Fiódor Dostoiévski foi uma das maiores personalidades da literatura russa, tido como fundador do Realismo. Entre suas obras destacam-se: Crime e Castigo, O Idiota, O Jogador, Os Demônios, O Eterno Marido e Os Irmãos Karamazov. 
ao fazer uma nova demonstração que o torne digno de respeito e admiração de novo. Para Goffman (2011, p. 20) um indivíduo: "[...] pode querer salvar sua própria fachada por causa de sua ligação emocional com a imagem do eu que sua fachada expressa, por causa de seu orgulho ou honra, por causa do poder que seu estatuto presumido permite que ela exerça sobre os outros participantes, e assim por diante". Desse modo, o Lenhador se torna herói ao fim da trama, visto que, ao longo de suas crises internas, supera as dificuldades e os próprios defeitos, restabelecendo a ordem das coisas.

Ao final da trama, o Lenhador assume estar com a fachada errada, sentindo-se constrangido e inferior, perdendo por um momento a reputação (Figura 3), pois a versão dos fatos que sustentava começa a cambalear, a desabar, trazendo constrangimento e mortificação, assim o personagem exprime uma fachada envergonhada. Goffman (2011, p. 16) relata o que acontece nesses casos: "[...] estar com a fachada errada ou fora de fachada para a fachada envergonhada pode adicionar mais desordem para a organização expressiva da situação".

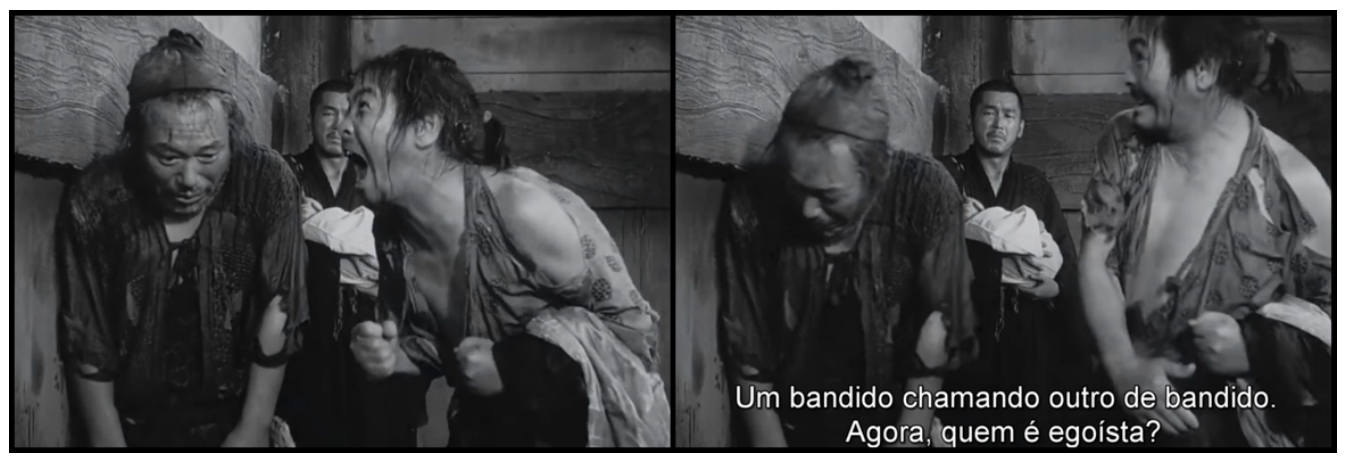

Figura 3 - O Lenhador é desmascarado e sente-se envergonhado.

Envergonhado, o Lenhador assume ter dupla voz: afirmar uma coisa em um momento e outra em outro, e acaba se posicionando na metade do caminho entre o correto e o errado, assim ele entra em crise, incapaz de agir e de resistir às tentações. Após a perda de sua fachada, um indivíduo pode tentar salvá-la por uma gama de motivos desde emoção até orgulho ou honra.

Um ato ofensivo pode despertar ansiedade quanto ao código ritual; o ofensor apazigua essa ansiedade demonstrando que tanto o código quanto ele, enquanto defensor do código, ainda funcionam. Depois do desafio e da oferta acontecerem, a terceira jogada pode ocorrer: as pessoas a quem a oferta é feita podem aceitá-la como um meio satisfatório de restabelecer a ordem expressiva e as fachadas apoiadas por essa ordem. Só então o ofensor pode terminar a parte principal de sua oferta ritual. $\mathrm{Na}$ jogada final do intercâmbio, a pessoa perdoada comunica um sinal 
de gratidão para aqueles que deram a ela a indulgência do perdão. (GOFFMAN, 2011, p. 28)

De forma mais clara, em Rashomon, o ato ofensivo cometido pelo Lenhador, e descoberto ao final da trama, reside no fato de não ter sido corajoso a ponto de enfrentar o Bandido e ter sido mau-caráter ao esconder a verdade sobre o crime para se beneficiar e se apossar da adaga. O Lenhador foi desonesto, ao contrário do que transparecia em sua fachada inicial. No entanto, apesar da ofensa, supera suas crises ao final da trama e se redime de seus maus atos ao defender um bebê abandonado no portal e ao adotá-lo.

Dessa maneira, o Lenhador salva a fé do Monge, ao adotar a criança, o qual confessa estar envergonhado por ter duvidado das boas intenções do Lenhador quanto ao bebê e, graças a ele, irá manter a sua fé nos homens (Figura 4). Em face disso, o Lenhador passa a ter direito novamente à proteção moral, à compaixão, à gratidão e à simpatia do Monge e do espectador do filme.

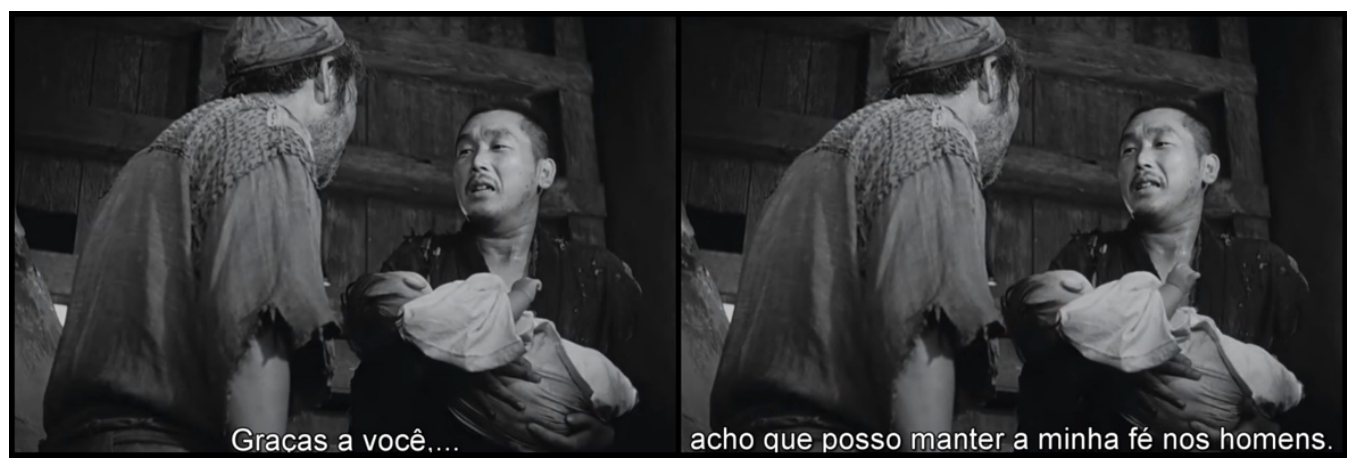

Figura 4 - O Lenhador passa a ter direito novamente à proteção moral e ao reconhecimento.

Paralelamente, há diversas semelhanças entre os romances de Dostoiévski com a obra de Akira Kurosawa: uma delas se funda na relação dialógica entre os enunciados distintos, que se dividem entre diversas vozes, mas que ficam em contato dentro de um mesmo tema comum. O tema de todos os enunciados se circunscreve na morte de um samurai e no estupro da esposa. Assim, as versões das seis pessoas a respeito do caso conversam entre si, embora com alguns pontos falsos. Os depoimentos se desenvolvem através de perspectivas diferentes, tendo em vista que toda linguagem é dialógica. Por outro lado, na narrativa de Rashomon, o herói é também um anti-herói, e com o autor Kurosawa se confundem e se fundem, o que é chamada de introspecção-confissão. Da mesma forma, Bakhtin analisa a introspeç̧ão-confissão na narrativa que estaria presente em quase todos os heróis dostoievskianos: 


\begin{abstract}
$\mathrm{Na}$ introspecção-confissão, não teremos nem herói nem autor, por não haver uma exotopia, uma posição de valor que Ihes permitiria a correlação: o herói e o autor se fundem, formam apenas um; é o espírito que prevalece sobre a alma num devir em que ele é inapto para encontrar o acabamento e mal pode a presunção de encontrar um pouco de consistência imperfeita em Deus (o espírito pode ter a presunção de encontrar um pouco de consistência imperfeita em Deus (o espírito tornado ingênuo). (BAKHTIN, 2003, p. 161).
\end{abstract}

Para Bakhtin (2003), a "introspecção-confissão" compreende a rejeição de um juízo divino ou humano, com tom desconfiante, colérico, havendo provocação e sinceridade. Percebe-se este tipo de discurso no filme, tanto no Monge quanto no Lenhador, principalmente porque de acordo com Yamashiro (1985), na era Heian, havia a propagação do pensamento chamado "Fim da Lei". Este era proveniente da escritura budista de que, após dois mil anos da morte de Buda, haveria uma degeneração do homem e da humanidade porque os ensinamentos dele perderiam o poder. Como neste período passou a haver sofrimento generalizado, causado por um desleixo da administração, surgiram mais perturbadores da ordem pública, crentes na ideia de "Fim da Lei". O Monge aparenta ser uma destas pessoas pessimistas com o "Fim da Lei" (Figura 5).

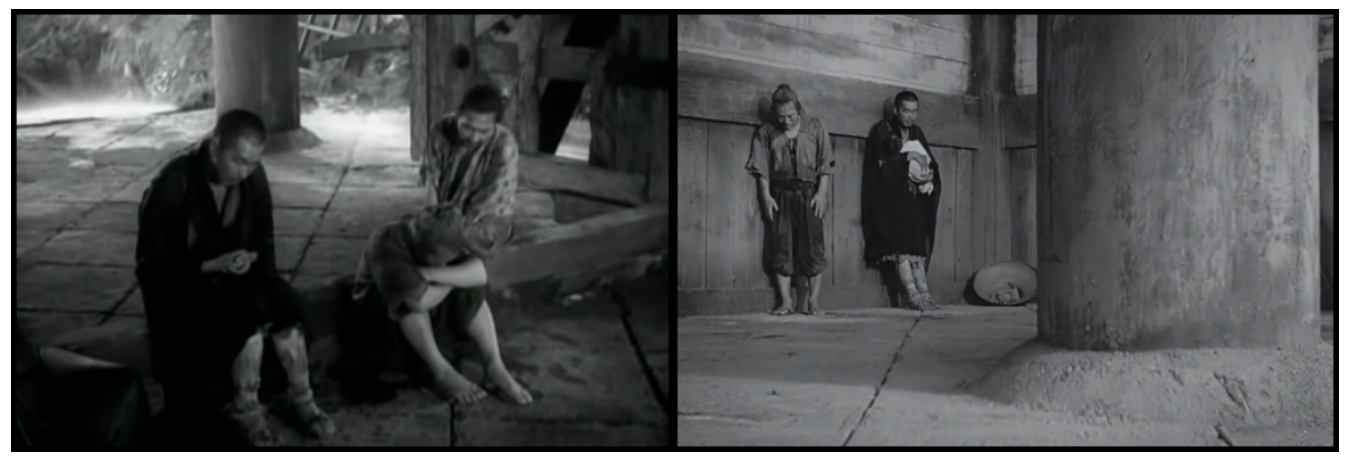

Figura 5 - Lenhador e Monge se mostram desolados.

Outras características bakhtinianas na obra de Kurosawa vêm por intermédio dos enunciados que interagem dialogicamente entre si de acordo com as situações sociais, inclusive historicamente, visto serem demarcados pelos gêneros, que legitimam e significam a produção de novos enunciados. Para Bakhtin (2003), os enunciados são historicamente dialógicos por serem interativos e dialogarem constantemente com outros enunciados anteriores, na construção dos sentidos. Rashomon, por exemplo, aprazia os japoneses por falar de sua cultura, remontar ao 
passado e usar o fato de a história ser contada por uma pessoa, o Lenhador, que remete aos benshis tão importantes para a cinematografia japonesa.

A interpretação dos atores mostra-se pouco natural e, às vezes, pouco convincente, por ser forçada, típica característica do teatro kabuki, expressão artística fortíssima da tradição e cultura japonesa que muito influiu o cinema no país. Russell relata que este tipo de cinema baseado no kabuki feito por cineastas como Kenji Mizoguchi, Naruse, Ozu e Kurosawa eram melodramas:

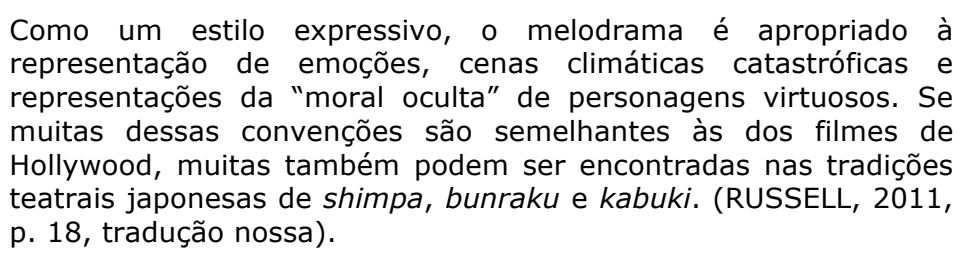

Em Rashomon vê-se na parte ambientada no palácio da justiça a acentuada influência do cinema kabuki advindo do teatro $k a b u k{ }^{1}$, pois a câmera reproduz o ângulo visual de um espectador do depoimento, no caso, o de quem os interrogava. O filme é considerado do gênero jidaigeki, pois dá ênfase na interpretação exagerada dos atores em poses (mie), a filmagem se realiza posicionando a câmera num ponto central do cenário e trata-se de um drama de época com orientação popular (RICHIE, 1971). Um dos casos mais relevantes deste tipo de interpretação é a do Monge e a do bandido Tajomaru que se voltavam na direção da câmera para mostrar suas expressões em alguns momentos.

\section{Considerações finais}

Considerando que o cinema representa as linguagens e os discursos do mundo e, por isso, é inegavelmente social e situado historicamente, além de ser construído para alguém com ideologias e discursos. Além disso, para Akira Kurosawa, o eurocentrismo das plateias pode influenciar as produções cinematográficas, pois estas plateias dominantes devem ser respeitadas para se obter o sucesso do filme, pois exercem a denominada "hegemonia indireta", conforme Stam e Shohat (2006). Além disso, a obra espelha os processos sociais mais amplos associados à produção. Os japoneses haviam passado muito tempo rejeitando a introdução de novas técnicas no cinema e ficado décadas impedindo o desaparecimento dos benshi e, provavelmente, agradou-Ihes assistir Rashomon.

\footnotetext{
${ }^{1}$ Kabuki é uma forma de teatro japonês, conhecida pelas máscaras e maquiagens exageradas. É muito dramático com artifícios que fazem o ator exprimir uma série de emoções e estados físicos.
} 
Neste sentido, o filme conseguiu manter o controle sobre o relato, apesar de possuir som, embora tenha sido imaginado por Kurosawa como um filme mudo. Por sua vez, ganha o espectador japonês por conter duas tramas já conhecidas e proporcionar um final de redenção, um reconforto para uma população desolada com a derrota na guerra e a destruição do país. Simultaneamente, agradou aos ocidentais por apresentar-lhes uma cultura diferente da conhecida de forma compreensível. O uso de mecanismos da narrativa baseado em novelistas ocidentais propiciou maior identificação do público ocidental já acostumado a este formato. Houve também a semelhança com o Western que aparece em Rashomon, pois a narrativas repetidas vezes parece ser uma jornada típica desse gênero, inclusive há uma cena externa no deserto em plano aberto de alguém que cavalga ao longe. Por fim, o jogo de luzes e sombras pode ter sido pensado pelo lado emocional, como se existissem muitas coisas do coração humano que permanecem nas sombras, escondidas da luz.

Em síntese, Kurosawa utilizava com maestria as influências do Ocidente e do Oriente, portanto, trata-se de um diretor que se manteve japonês, mas impregnou sua obra de um sentimento encontrado nos autores europeus do final do século XIX, pois tinha a intenção de chamar a atenção de orientais e ocidentais para as questões humanas de valorização dos indivíduos, enquanto participantes da vida social em geral. Na análise do filme Rashomon não apenas se revelou ser possível fazer uma imersão na questão teórica, como também conhecer um pouco mais a biografia de Akira Kurosawa e de um país moderno inserido nas performances históricas e sociais do Japão e do restante do mundo.

\section{Referências}

AKUTAGAWA, Ryûnosuke. Rashômon e outros contos. São Paulo: Hedra, 2008.

BAKHTIN, Mikhail. Problemas da Poética de Dostoiévski. Rio de Janeiro: Forense Universitária, 1981.

. Estética da Criação Verbal. São Paulo: Martins Fontes, 2003.

Marxismo e filosofia da linguagem. São Paulo: Hucitec, 2014.

BAUMAN, Richard. Verbal Art as Performance. Illinois: Waveland, 1977.

A world of others' words: cross-cultural perspectives on intertextuality. Oxford: Blackwell Publishing, 2004.

FARRINGTON, Karen. História ilustrada da religião. 1. ed. São Paulo: ABBA, 1999. 
GOFFMAN, Erving. Ritual de interação: ensaios sobre o comportamento face a face. Petrópolis, RJ: Vozes, 2011.

A representação do eu na vida cotidiana. Petrópolis, RJ: Vozes, 2014.

HARTMANN, Luciana. Performance e experiência nas narrativas orais da fronteira entre Argentina, Brasil e Uruguai. Horiz. antropol., v. 11, n. 24, p. 125-153, 2005.

KUROSAWA, Akira. Akira Kurosawa: something like an autobiography. Nova York, Toronto: Vintage Books, 1982.

RICHIE, Donald. Japanese Cinema: film style and national character. Nova York: Anchor Books, 1971.

RUSSELL, Catherine. Classical Japanese Cinema: Revisited. Nova York: The Continuum International Publishing Group, 2011.

STAM, Robert; SHOHAT, Ella. Crítica da imagem eurocêntrica. São Paulo: Cosac \& Naify, 2006.

UEDA, Makoto. Modern Japanese writers and the nature of literature. São Francisco: Stanford University, 1976.

WERTSCH, J. V. Voices of collective remembering. Nova York: Cambridge University Press, 2004.

YAMASHIRO, José. História da cultura japonesa. São Paulo: Ibrasa, 1985.

RASHOMON. Direção de Akira Kurosawa. Japão: Versátil Digital Filmes, 1950. 1 DVD (88 min). 